\title{
Conservation status of fish and marine invertebrate of rocky reefs and sandy substrates in two unprotected bays of the Papagayo Gulf, Costa Rica
}

\author{
Keilor E. Cordero-Umaña ${ }^{1,2}$ \& Pilar Santidrián-Tomillo ${ }^{2}$ \\ 1. Menéndez Pelayo International University, Madrid, Spain; kecu2011@gmail.com \\ 2. The Leatherback Trust, Goldring-Gund Marine Biology Station, Playa Grande, Costa Rica; Bibi@leatherback.org
}

Received 26-V-2020. Corrected 12-VIII-2020. Accepted 07-IX-2020.

\begin{abstract}
Introduction: North Pacific Costa Rica is generally considered rich in marine habitats and species. However, some areas are subject to fishing pressures that could degrade ecosystems. The Gulf of Papagayo comprises protected and unprotected areas with various degrees of impact. Objectives: Our aim was to evaluate the conservation status of fish and invertebrate communities in rocky reefs and sandy areas in two unprotected bays of the Gulf of Papagayo. Methods: The study was conducted at Cabuyal and Zapotillal Bays, south of Santa Rosa National Park. From December 2017 to April 2018, a total of thirty-five transects were done parallel to the coast at 3-10 m depth. We identified fish and invertebrate species and estimated biomass by trophic group in fish, and density in invertebrates. Results: We found a high number of species of fish (81) and invertebrates (70) in rocky reefs, which indicates a biodiverse ecosystem, but few species of fish in sandy areas. Species composition differed between the two bays. Density of juvenile fishes was high in Zapotillal Bay, suggesting that the area could be important for recruitment and breeding. Fish biomass was higher in sandy areas than in rocky reefs and all trophic groups had lower biomass than in other unprotected areas of the region. On average, reef fish biomass was $1.57 \pm 0.67$ (s.e.) t ha ${ }^{-1}$, similar to previous reports for Costa Rican North Pacific. By trophic group, piscivorous and planktivorous had the highest biomass in sandy areas and piscivorous and carnivorous in rocky reefs. Mean coral cover was low with $4.09 \% \pm 2.51$ (s.e.), similar to previously reported for the region. Conclusions: Cabuyal and Zapotillal Bays in the Gulf of Papagayo are biodiverse in fish and invertebrates. However, the area may be impacted by local fisheries and other human activities, affecting fish and invertebrate populations, and coral formations. Our study fills some gaps in knowledge of marine biodiversity in the Gulf of Papagayo that can contribute to the conservation of marine life in North Pacific Costa Rica.
\end{abstract}

Key words: knowledge gap; Guanacaste Conservation Area; unprotected marine areas; reef health; overfishing.

Cordero-Umaña, K.E., \& Santidrián-Tomillo, P. (2020). Conservation status of fish and marine invertebrate of rocky reefs and sandy substrates in two unprotected bays of the Papagayo Gulf, Costa Rica. Revista de Biología Tropical, 68(4), 1311-1321.

Research on marine biodiversity lags behind that of terrestrial biodiversity in many tropical countries. The North Pacific region of Costa Rica is home to a wide variety of coastal ecosystems, including estuaries, mangroves, intertidal zones, beaches of different composition, coral reef patches and islands, which makes the area especially complex (Cortés, 2017). Within the Costa Rican North Pacific, several studies have been conducted on coral reef health and community structure, with some of them reporting high species richness in invertebrates and fishes (Cortés-núñez, Molina-Ureña, \& Quesada-Alpizar, 2005; Dominici-Arosemena, Brugnoli-Olivera,; Espinoza \& Salas, 2005; Sibaja-Cordero, Camacho-García, \& Vargas-Castillo, 2014; Alvarado et al., 2018;). The area however, has faced significant urban development in recent years, and is one of the fastest growing areas for the tourist and 
fishing sectors in the country, contributing to the degradation of marine ecosystems and affecting their biodiversity (Morales-Ramírez, 2013; Villalobos-Rojas, Herrera-Correal, Garita-Alvarado, Clarke, \& Beita-Jiménez, 2014).

The Gulf of Papagayo contains a Marine Protected Area (MPA) that is part of Santa Rosa National Park, but most of the Gulf is unprotected. Thus, fisheries operating outside the Santa Rosa MPA could affect fish and invertebrate communities. MPAs contribute to conservation and/or restoration of key species and habitats by reducing human pressure, becoming reference points for the conservation of marine communities (Strain et al., 2019). Protected areas benefit fish populations of all trophic groups, registering high biomasses of all, which can extend to nearby exploited populations (Soler et al., 2015). MPAs can also positively affect fish populations in adjacent areas through natural dispersal of juveniles (Marshall, Gaines, Warner, Barneche, \& Bode, 2019).

Cabuyal and Zapotillal are two unprotected bays in the Gulf of Papagayo where fish and marine invertebrate communities have not previously been assessed. This area is of interest because of its closeness to the MPA of Santa Rosa National Park and because fisheries operate nearby. Thus, the study area could benefit from its location next to a National Park. Our aim was to evaluate the conservation status of fish and invertebrate communities of Cabuyal and Zapotillal Bays in rocky reefs and sandy areas. We assessed species richness and fish biomass by trophic group, compared densities of juvenile and adult fish and estimated species richness and density of invertebrates. Our work aims also to fill some gaps in knowledge to ultimately contribute to conserve marine life in North Pacific Costa Rica.

\section{MATERIALS AND METHODS}

Study site: The study was conducted during the dry season, between December 2017 and April 2018 in the bays of Cabuyal $\left(10^{\circ} 67^{\prime} 42^{\prime \prime} \mathrm{N} \& 85^{\circ} 65^{\prime} 43 \mathrm{~W}\right)$ and Zapotillal $\left(10^{\circ} 65^{\prime} 77^{\prime \prime} \mathrm{N} \& 86^{\circ} 67^{\prime} 13^{\prime \prime} \mathrm{W}\right)$, at the southern end of the Papagayo Gulf, Northwest Costa Rica (Fig. 1). Cabuyal Bay has an area of $5 \mathrm{~km}^{2}$ with reefs composed of large boulders and Zapotillal is a closed bay of $\sim 530 \mathrm{~m}^{2}$ with rock platform reefs and rock walls. The area is a high-energy zone with sandy beaches, and its northern and southern extremes are composed of rocky areas with cliffs. At the southern end of Cabuyal there is an estuary, associated with mangroves that receives freshwater during the rainy season from the seasonal stream Cacao (Windevoxhel Lora \& Cordoba Muñoz, 1998). Zapotillal is also surrounded by well-preserved mangroves (Yaney-Keller, Santidrián Tomillo, Marshall, \& Paladino, 2019), but with less freshwater inflow. Both bays are influenced by seasonal wind-driven coastal upwelling, occurring between December and April, that brings cold and productive waters to the coast (Alfaro \& Cortés, 2012).

\section{Quality estimators and species richness:} The inventory quality (QI), was estimated using the Clench parametric estimator model. QI represents the percentage of species that were recorded out of the total that can inhabit the area. Number of transects was used as unit effort, and data were adjusted following the Clench equation (Jiménez-Valverde \& Hortal, 2003). The model was adjusted to the Simplex and Quasi Newton method to obtain parameters $\mathrm{i}$ and $\mathrm{c}$, which allowed calculation of the slope at the end of the curve to better evaluate inventory quality (Jiménez-Valverde \& Hortal, 2003). We used the following equation to determine the inventory quality:

$$
\mathrm{QI}=\operatorname{Sobs} /(\mathrm{i} / \mathrm{c})
$$

Where $\mathrm{i}=$ intercept, $\mathrm{c}=$ curve slope, $\mathrm{QI}=$ Inventory quality and Sobs $=$ observed species per site.

To estimate sampling effort needed to record $95 \%$ of the fauna (n0.95) we used:

$$
\mathrm{n} 0.95=0.95 /[\mathrm{c} *(1-0.95)]
$$




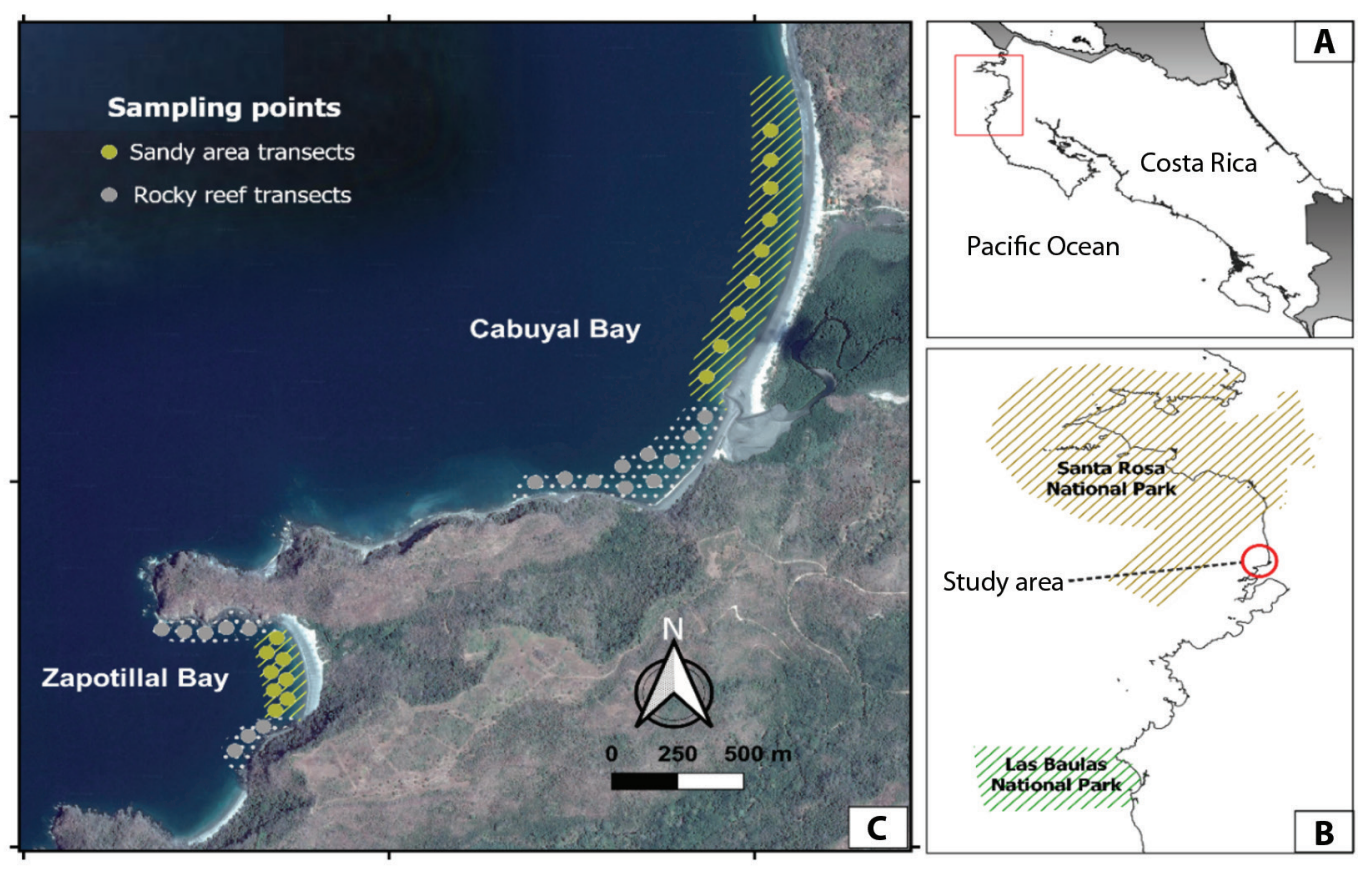

Fig. 1. Location of sampling transects in Cabuyal and Zapotillal Bays, Papagayo Gulf. A. Map of Costa Rica showing the study area. B. Location of study area in relation to marine protected areas. C. Transects carried out in sandy zones (yellow) and rocky reefs (gray) at Cabuyal and Zapotillal Bays. Dotted areas correspond to rocky reef areas sampled and lines to sandy areas. Map data property of Google Maps (https:/www.google.com/maps/) and Atlas Costa Rica 2014 TEC repository (https://repositoriotec.tec.ac.cr).

We estimated species richness of the study site using four nonparametric biodiversity estimators: Jack 1, ICE and Chao 1 which consider rare species, and Bootstrap estimator. In our study we found most of the species in few sampling units, which means that if we continued sampling the species found would be rare species. Thus, these indexes give a good approximation of richness, because they take in consideration rare species that may be in the study area. Study site diversity was calculated using the Shannon index (H'); this index typically ranges between 2 and 3, with values higher than 3 representing high diversity and lower than 2 low diversity (Hill, 1973). Beta diversity was calculated with the Whittaker index (w), with values close to 1 indicating high turnover of species between two sites and values close to 0 indicating high heterogeneity of species (Whittaker, 1960).
Data collection: For fish sampling, we conducted underwater visual censuses with snorkel equipment. Eight to ten belt transects (50 $\mathrm{m}$ long, $5 \mathrm{~m}$ wide) (Fig. 1) were performed between 3 to $10 \mathrm{~m}$ depth (nine and ten for Cabuyal and eight and eight for Zapotillal in sandy areas and rocky reef respectively). Transects were defined uniformly throughout the study area. Two runs were made along each transect. The first run was done while the line was being unrolled, recording all conspicuous species in the water column (except the cryptic and less conspicuous ones, e.g. gobies and blennies). In the second one, the observer recorded cryptic looking species in the benthos, under rocks and between cracks. This methodology allowed us to first identify species susceptible to being frightened (Aburto-Oropeza $\&$ Balart, 2001). We estimated the size of each fish by using a PVC tube marked with intervals 
every five $\mathrm{cm}$. Those sizes were transformed to biomass and expressed in tons per hectare $\left(\mathrm{t} \mathrm{ha}^{-1}\right)$ using the equation from Friedlander et al. (2012). To estimate biomass we used the Bayesian weight-length ratio (LWR) parameters $\mathrm{a}$ and $\mathrm{b}$ from Fishbase, based on many studies done on body shape and size (Froese \& Pauly, 2020).

According to Fishbase food items, each species was classified in four different functional trophic groups: herbivores (primary consumers and detritivores); planktivorous (secondary consumers); carnivores (benthic invertebrate carnivores) and piscivores (fish predators). Fishes were classified as adult or juveniles based on maturity studies included in Fishbase, which considered length at first maturity $\left(\mathrm{L}_{\mathrm{m}}\right)$ for different species and it range. For those species without $\mathrm{L}_{\mathrm{m}}$ information, we used Fishbase common length size (frequent sizes for the species) to classify them. Cryptic species like blennies and gobies were all classified as adults because their sizes were in the range of maximum sizes for the species, according to Fishbase.

For invertebrates, we made $50 \mathrm{~m}$ band transects (50 m long, $1 \mathrm{~m}$ wide) to the right side of the line (ten and eight transects for Cabuyal and Zapotillal Bays respectively). Transects were done in rocky areas only, since settlements of macroinvertebrates on sandy substrates are rare. Invertebrates were classified into two groups: (1) colonies or (2) solitary invertebrates.

Colonial organisms (stony corals, soft corals, anemones, hydrozoans) and sponges were treated as circular organisms. By this way, we obtained a system of not superimposed circles on the plane to easily calculate the area covered by each one (Ulate et al., 2016). During each transect, the diver identified solitary invertebrates (mobile and sessile) that were greater than $2.5 \mathrm{~cm}$. Density was estimated and expressed as organisms per square meter (org $\mathrm{m}^{-2}$ ). Soft corals, gorgonians, anemones, sponges, and hydrozoans were also included in density analysis. We followed Keen (1972) and Camacho-García, Gosliner and Valdés (2005) to identify mollusks, Hickman (1998) for echinoderms and Brusca (1974) and Fischer et al. (1995) for other invertebrates. Rocks or other habitat structures were not removed during the survey.

Statistical analyses: We estimated the four non-parametric biodiversity estimators using 100 sample randomizations, to eliminate the effect of order in which samples were added. To determine if there were statistical differences between densities of juvenile and adult fish, a generalized linear model (GLM) with gamma error distribution family was used, testing assumptions of normality and homoscedasticity. We used an ANOVA to compare trophic groups by bays and habitats (assumptions of normality and homoscedasticity were met). All analyses were performed using $\mathrm{R}$ Core Team version 3.5.2 (2018) except the nonparametric biodiversity estimators, which were inferred using the program EstimateS version 9.1.0. (Colwell, 2013) and Statistica version 10.0 (StatSoft-Inc., 2011). An $\alpha=0.05$ was accepted for all tests performed.

\section{RESULTS}

A total of 27679 specimens in 174 species were identified during the sampling period (see supplementary materials for a list of species, Digital appendix 1, Digital Appendix 2). We identified 136 species (85 fish and 51 invertebrate species) and 127 species (73 fish and 54 invertebrate species) at Cabuyal and Zapotillal Bays respectively (Table 1). Outside transects, we also identified nurse sharks (Ginglymostoma unami) but these were not included in the analysis.

Quality estimators and species inventory richness: Adjusting the Clench parametric model resulted in an inventory quality greater than $71 \%$ for both fish and invertebrates in the rocky reef. However, the inventory representativeness of fish in sandy areas was less than $59 \%$ (Table 1). Beta diversity in all the cases 
TABLE 1

Number of observed species, diversity estimated with non-parametric methods (Jack 1, ICE, Chao 1, and Bootstrap), inventory representativeness by Clench model (inventory quality and n0.95) and Shannon and Beta diversity indexes for the study areas

\begin{tabular}{|c|c|c|c|c|c|c|}
\hline \multirow{3}{*}{ Faunistic indexes } & \multirow{2}{*}{\multicolumn{2}{|c|}{ Invertebrates }} & \multicolumn{4}{|c|}{ Fishes } \\
\hline & & & \multicolumn{2}{|c|}{ Sandy areas } & \multicolumn{2}{|c|}{ Rocky reefs } \\
\hline & $\mathrm{CAB}$ & ZAP & $\mathrm{CAB}$ & ZAP & $\mathrm{CAB}$ & ZAP \\
\hline Number of observed species & 51 & 54 & 29 & 23 & 69 & 60 \\
\hline Jack 1 & 67 & 65 & 44 & 36 & 92 & 69 \\
\hline ICE & 74 & 63 & 65 & 64 & 92 & 65 \\
\hline Chao 1 & 63 & 56 & 41 & 27 & 84 & 69 \\
\hline Bootstrap & 57 & 60 & 35 & 29 & 79 & 65 \\
\hline Inventory quality (\%) & 71 & 74 & 59 & 48 & 79 & 86 \\
\hline n0.95 & 83 & 51 & 124 & 171 & 54 & 25 \\
\hline Shannon index & 2.25 & 2.50 & 1.47 & 1.52 & 3.16 & 2.61 \\
\hline Beta diversity & \multicolumn{2}{|c|}{0.47} & \multicolumn{2}{|c|}{0.50} & \multicolumn{2}{|c|}{0.26} \\
\hline
\end{tabular}

$* \mathrm{CAB}$ and ZAP correspond to Cabuyal and Zapotillal Bays, respectively, n095: sampling effort needed to record $95 \%$ of the fauna. Beta diversity was calculated for the exchange of species between bays.

was below 0.50 , showing differences in species composition between bays.

Fish density and biomass: Mean rocky reef fish biomass ( \pm standard error; samples) in the study area was $1.57 \mathrm{t} \mathrm{ha}^{-1}( \pm 0.67 \mathrm{SE}$; $\mathrm{N}=13621)$, with $2.42 \mathrm{t} \mathrm{ha}^{-1}( \pm 0.04 \mathrm{SE} ; \mathrm{N}=$ 4 322) in Cabuyal Bay and $0.72 \mathrm{t} \mathrm{ha}^{-1}( \pm 0.01$ $\mathrm{SE} ; \mathrm{N}=9$ 299) in Zapotillal Bay. On average, we found higher biomass in sandy areas than in rocky reefs, with $4.64 \mathrm{t} \mathrm{ha}^{-1}( \pm 0.19 \mathrm{SE} ; \mathrm{N}=$ $6038)$ and $3.04 \mathrm{t} \mathrm{ha}^{-1}( \pm 0.29 \mathrm{SE} ; \mathrm{N}=3$ 466) for Cabuyal and Zapotillal sandy areas, respectively. There were statistically significant differences between biomass of trophic groups $(\mathrm{F}=14.7$, d.f. $=583, \mathrm{P}<0.001)$. Biomass of piscivorous fishes was higher in rocky reefs, followed by carnivorous fishes, in both Cabuyal and Zapotillal Bays (Fig. 2A). Sandy areas had a higher biomass of piscivorous and planktivorous fish (Fig. 2B). A total of 13931 fishes were classified as adults, while 9194 were juveniles including both sites. Mean densities of adults were higher than that of juveniles at both study sites (Fig. 2C). These differences were statistically significant at Cabuyal Bay $\left(\mathrm{X}^{2}=5.04\right.$, d.f. $\left.=1, \mathrm{P}<0.05\right)$, but not at Zapotillal Bay $\left(X^{2}=0.01\right.$, d.f. $\left.=1, P=0.91\right)$.
Coverage of colonial organisms and density of invertebrates: we identified a total of 11 coral species dispersed on the rocky reef, of which 7 species were found in Zapotillal Bay (5 hexacorals and 2 octocorals) and 6 species in Cabuyal Bay (3 hexacorals and 3 octocorals). One hexacoral of the order Scleractinia could not be identified in Cabuyal Bay during the sampling. Mean coral cover in the substrate for the study area was $4.09 \%( \pm 2.51 \mathrm{SE} ; \mathrm{N}=$ $50)$, with a mean of $11 \%( \pm 0.21 \mathrm{SE} ; \mathrm{N}=21)$ in Cabuyal Bay and $4 \%( \pm 0.09 \mathrm{SE} ; \mathrm{N}=29)$ in Zapotillal Bay. Porites panamensis and Porites lobata represented the greatest mean coral cover in the study area (Fig. 3). Other colonial organisms such as soft corals, gorgonians, sponges, hydrozoans, and anemones comprised a mean cover of $5 \%( \pm 0.40 \mathrm{SE} ; \mathrm{N}=230)$ and $4 \%( \pm 0.32 \mathrm{SE} ; \mathrm{N}=206)$ for Cabuyal and Zapotillal Bays, respectively.

Echinoderms were the group of invertebrates with the highest mean density followed by chordate, mollusks, and arthropods (Fig. 4A, 4B). At the species level, the highest mean density was sea urchin Diadema mexicanum and ascidia Ropalaea birkelendi in Cabuyal Bay, and sea urchin D. mexicanum and Echinometra vanbrunti in Zapotillal (Fig. 4A, 4B). 

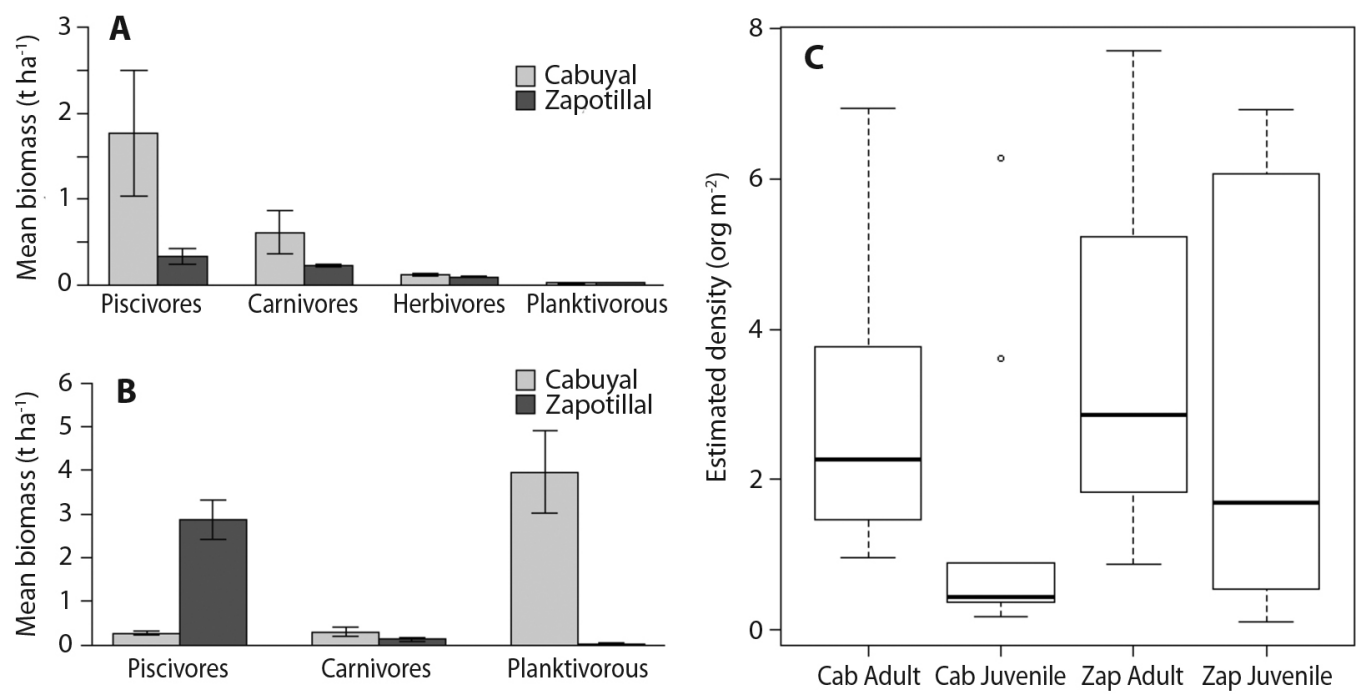

Fig. 2. Mean estimated biomass of trophic levels with standard error bars in A. the rocky reefs and B. sandy areas, and C. Mean density of developmental stages adults and juveniles in Cabuyal (Cab) and Zapotillal (Zap) Bays (box represents 1st quartile (top of box) and 3rd quartile (bottom of box) with the black line indicating median value. Whiskers represent minimum (lower) and maximum (upper) with outliers shown as open circles).

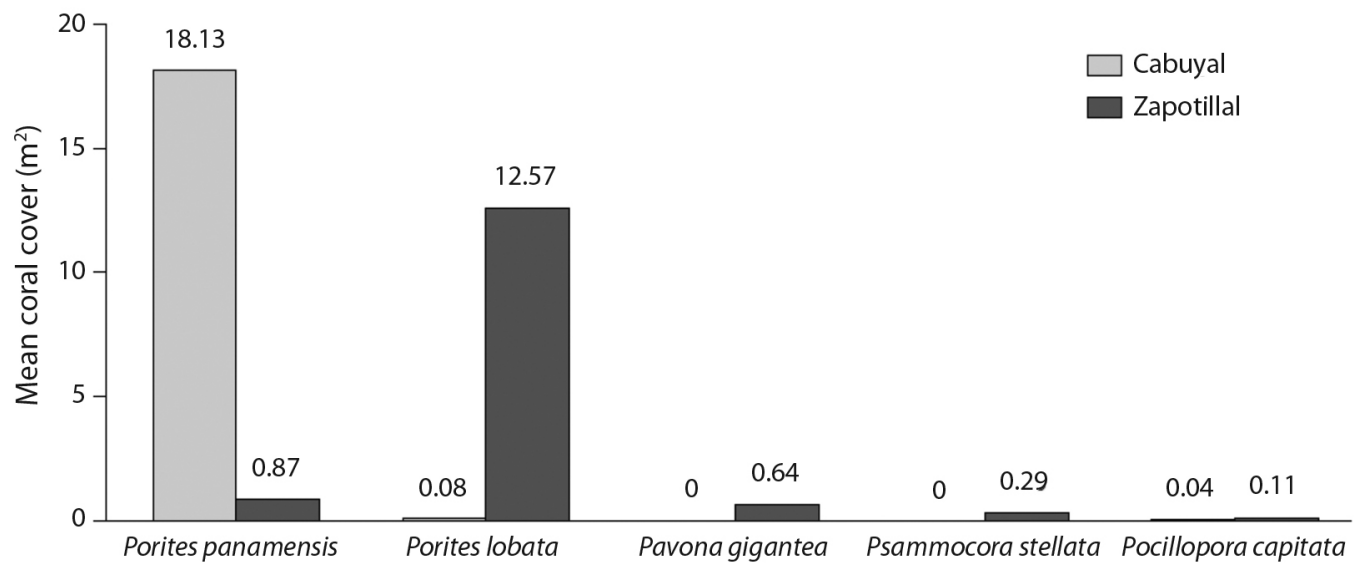

Fig. 3. Mean estimated stony coral cover at Cabuyal and Zapotillal Bays.

In general, the dominant mobile invertebrates in Zapotillal had a higher density of organisms per square meter than those dominant in Cabuyal. Among solitary invertebrates, seven species could not be identified.

\section{DISCUSSION}

Quality estimators and species richness: The quality of our inventory was high in rocky reefs as proportions above $70 \%$, indicate that estimates of asymptotic richness are stable (Jiménez-Valverde \& Hortal, 2003). However, $\sim 50 \%$ of fish species may not have been recorded in sandy areas. Due to their very dynamic nature, many species move through sandy zones with the tide (Herrera \& Bone, 2015; Andrade-Vera, Domínguez-Granda, \& Marín-Jarrín, 2017), likely reducing inventory representativeness. 

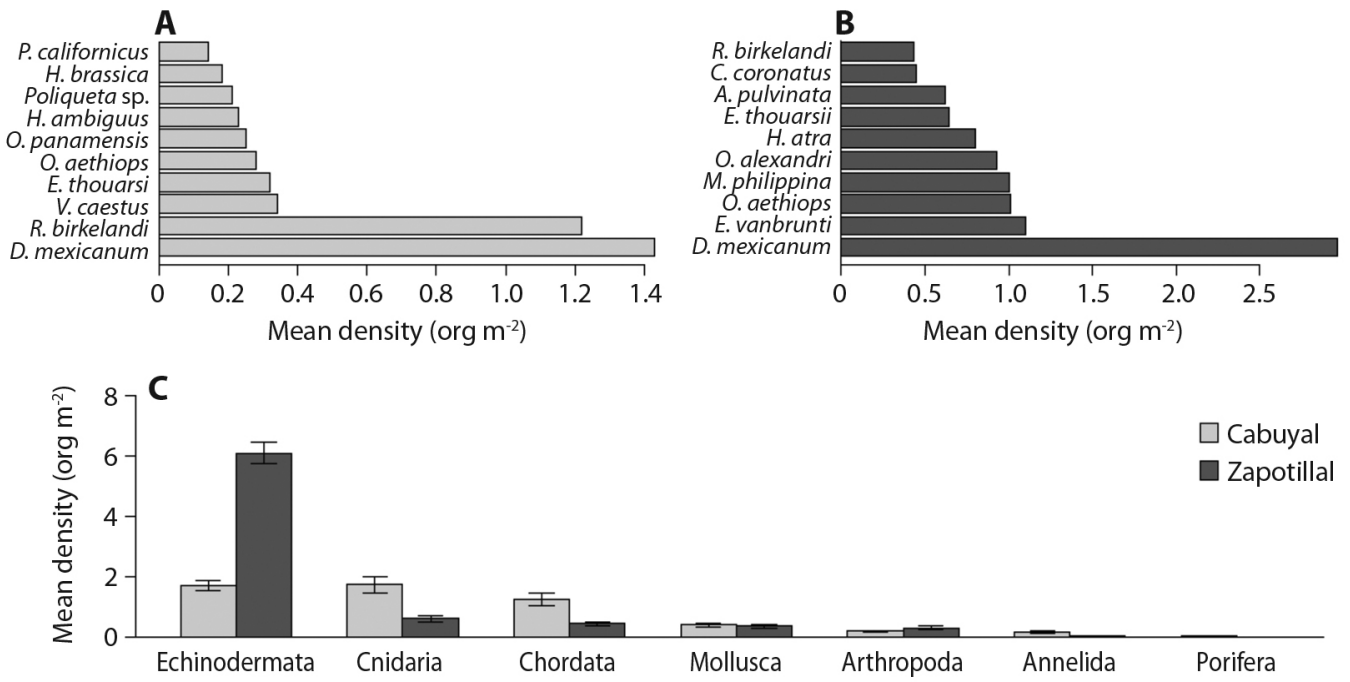

Fig. 4. Mean estimated density per species and Phylum of invertebrates in the study areas. Figure shows the 10 most dominant solitary invertebrates at A. Cabuyal Bay, B. Zapotillal Bay and C. the dominance per Phylum at both bays with standard error bars.

Espinoza and Salas (2005) and DominiciArosemena, Brugnoli-Olivera, Cortés-Núñez, Molina-Ureña and Quesada-Alpizar (2005) respectively reported 46 and 75 fish species in rocky reefs in the Papagayo Gulf. We found a higher number of species (81) following a different methodology. Our methodology included doing a second round to account for cryptic fish species, which likely resulted in a more complete inventory. At rocky reefs, we identified more invertebrates (70 species) than previously reported for coral reefs (38 species) in North Pacific Costa Rica. Our results suggest that rocky reefs in North Pacific Costa Rica hold a high number of species, however reefs have been strongly affected by human impacts in the region in recent years (Alvarado et al., 2018). MPAs are not always located in the areas with the highest biodiversity or are not large enough to fully protect highly diverse areas, leaving unprotected areas of high biodiversity subject to human exploitation (Sibaja-Cordero et al., 2014), as could be the case of the study sites.

Beta diversity showed that communities of both bays had different species compositions of both fish and invertebrates. Rocky areas are complex ecosystems with high heterogeneity in composition and structure, offering shelter to a wide number of species (Dominici-Arosemena \& Wolff, 2006; García-Hernández et al., 2014). Boulders and walls such as those present in the study area, are characterized by a high number of crevices and rugosities favoring the settlement and refuge of different species (Aburto-Oropeza \& Balart, 2001). Furthermore, environmental factors such as the input of sediments and nutrients from mangroves can also shape species composition, favoring organisms like the ascidian $R$. birkelandi found in Cabuyal Bay (Dittmar \& Lara, 2001). The biological diversity of the substrate also favors settlement of other species (Aburto-Oropeza $\&$ Balart, 2001). Coral coverages and organisms such as sponges, anemones, hydrozoans, and soft corals like those found in the study area, provide substrate for recruitment, feeding habits and refuge from predation (Ferreira, Goncçalves, \& Coutinho, 2001).

Biomass, trophic groups, and juvenile fishes: reef fish biomass at Cocos Island National Park (Costa Rica), a biodiversity hotspot highly protected from fishing, was estimated as $12.5 \mathrm{t} \mathrm{ha}^{-1}$ (Fourriére et al. 2019), 
much higher than what we found $\left(1.57 \mathrm{tha}^{-1}\right)$. However, North Pacific Costa Rica has been subjected to habitat loss and intense fishing and fish biomass here is much lower $\left(1.5 \mathrm{t} \mathrm{ha}^{-1}\right.$ Alvarado et al., 2018) and similar to our findings. This suggest that Cabuyal and Zapotillal Bays, similarly to other areas in the region, (Villalobos-Rojas et al., 2014), have suffered impacts from fishing and habitat loss.

MPAs benefit all trophic groups, but recovery is usually faster in large carnivorous fish due to their rapid growth (Soler et al., 2015). Protection results in a high biomass of mobile fish that can also affect surrounding areas (Beita-Jiménez et al., 2019). We found higher biomasses of piscivorous and carnivorous fish in rocky reefs, which could suggest a possible impact from the nearby MPA of Santa Rosa. However, except for piscivorous fishes in Cabuyal Bay, we found lower biomass of fish in all trophic groups than those reported for other unprotected areas in the region (BeitaJiménez et al., 2019). Despite being close to a MPA, fish populations of Cabuyal and Zapotillal Bays seem affected by fisheries, possibly as a result of lack of regulations and low level of compliance in the region (Arias, Cinner, Jones, \& Pressey, 2015).

While predatory fishes are most heavily exploited, herbivores are also targeted by artisanal fisheries, which may lead to reduced grazing of macroalgae, negatively affecting live coral cover (Jennings \& Polunin, 1997; Edwards et al., 2014). In Costa Rican North Pacific, coral cover has declined from 43 to 5 $\%$ in the last 15 years, and reefs have become macroalgae dominated (Alvarado et al., 2018). This leads to high densities of other herbivores such as the sea urchin D. mexicanum, which affects coral recruitment (Alvarado, Cortés, \& Reyes-Bonilla, 2012). Thus, the low coral cover and high density of $D$. mexicanum that we found could be explained by a low biomass of herbivorous fish, similar to that reported by Alvarado et al. (2018).

We found high densities of juvenile fishes, especially at Zapotillal Bay. Alvarado et al. (2018) also reported a high percentage of juveniles in several reefs of North Pacific Costa Rica. MPAs are known to benefit fish recruitment, exporting juveniles to surrounding areas (Marshall et al., 2019). In addition, North Pacific Costa Rica is rich in rocky ecosystems (Cortés, 2017), which provide a variety of shelters to avoid pelagic and benthic predators (Moreno Pérez, 2019). Thus, Zapotillal Bay seems important for recruitment and breeding of fish populations, especially considering that the area is impacted by fisheries. Our study reports for the first-time fish biomass for sandy areas in the Papagayo Gulf. The presence of big schools of piscivorous and planktivorous fishes with high biomasses characterized the site. Sandy areas are considered heterogeneous and complex habitats (Moreno Pérez, 2019), so further studies are needed to describe species composition, as well as their dynamics.

Implications for conservation: This is one of few studies done on fish and invertebrate communities of rocky reefs and sandy areas in the Papagayo Gulf. We found high biodiversity of fish and marine invertebrates in rocky reef environments and identified some invertebrates threatened by overfishing such as the green lobster Panulirus gracilis and the sea cucumber Isostichopus fuscus ( Naranjo-Madrigal, 2011; Mercier, Toral-Granda, Alvarado, \& Benavides-Serrato, 2013). The area could be benefitting from its closeness to the Santa Rosa MPAs. Densities of juvenile fish were especially high in Zapotillal Bay, suggesting that the area may be a breeding site contributing to the maintenance and resilience of reef fish populations. On the other hand, the area seems to be under fishing pressure, affecting all trophic groups. The low coral cover found also confirms that coral ecosystems are highly affected by degradation along the North Pacific coast of the country, mainly by eutrophication, overfishing and urban development (Alvarado et al., 2018). Our findings contribute to the description of marine biodiversity in rocky reef and sandy areas of the Papagayo Gulf. We expect that this information will serve for initiatives such as the BioMar Costa Rica project 
to increase knowledge of the country's marine biodiversity, which will ultimately contribute to the conservation of marine life in the region.

Ethical statement: authors declare that they all agree with this publication and made significant contributions; that there is no conflict of interest of any kind; and that we followed all pertinent ethical and legal procedures and requirements. All financial sources are fully and clearly stated in the acknowledgements section. A signed document has been filed in the journal archives.

\section{ACKNOWLEDGMENTS}

We thank all team members and volunteers from the sea turtle project at Playa Cabuyal who assisted in this study, especially Javier López-Navas, Adam Yaney-Keller and Verónica Valverde-Cantillo. We also thank Adam Yaney-Keller for comments on the manuscript. We would also like to thank The Leatherback Trust for logistical support during the season and professors Karol Ulate (UNA, Costa Rica) and José Serrano (CSIC, Spain) for advice in sampling methods and data analysis. A special thanks to ACG for providing scientific permits and in particular to Roger Blanco.

\section{RESUMEN}

Estado de conservación de peces e invertebrados marinos de arrecifes rocosos y zonas arenosas en dos bahías desprotegidas del Golfo de Papagayo, Costa Rica. Introducción: El Pacífico Norte de Costa Rica generalmente se considera rico en hábitats y especies marinas. Sin embargo, algunas zonas están sujetas a presiones de pesca que pueden degradar los ecosistemas. El Golfo de Papagayo comprende zonas protegidas y desprotegidas con diversos grados de impacto. Objetivos: Nuestro objetivo fue evaluar el estado de conservación de las comunidades de peces e invertebrados en los arrecifes rocosos y las zonas arenosas de dos bahías desprotegidas del Golfo de Papagayo. Métodos: El estudio se llevó a cabo en las bahías de Cabuyal y Zapotillal, al sur del Parque Nacional Santa Rosa. Desde diciembre 2017 hasta abril 2018, se realizaron un total de 35 transectos paralelos a la costa entre 3-10 $\mathrm{m}$ de profundidad. Se identificaron especies de peces e invertebrados y se estimó la biomasa por grupo trófico en los peces, y la densidad en los invertebrados. Resultados:
Encontramos un alto número de especies de peces (81) e invertebrados (70) en arrecifes rocosos, lo que indica un ecosistema biodiverso, pero pocas especies de peces en zonas arenosas. La composición de especies difirió entre las dos bahías. La densidad de peces juveniles fue elevada en la bahía de Zapotillal, lo que sugiere que la zona podría ser importante para el reclutamiento y la reproducción. La biomasa de peces fue mayor en zonas arenosas que en arrecifes rocosos y todos los grupos tróficos tuvieron menores biomasas que en otras zonas desprotegidas de la región. En promedio, la biomasa de peces de arrecifes fue de 1.57 \pm 0.67 (s.e.) $\mathrm{t} \mathrm{ha}^{-1}$, similar a lo reportado anteriormente en el Pacífico Norte de Costa Rica. Por grupo trófico, los piscívoros y planctívoros tuvieron la biomasa más alta en las zonas arenosas y los piscívoros y carnívoros en los arrecifes rocosos. La cobertura media de coral fue baja con $4.09 \% \pm 2.51$ (s.e.), similar a la reportada anteriormente para la región. Conclusiones: Las bahías Cabuyal y Zapotillal en el Golfo de Papagayo son biodiversas en peces e invertebrados. Sin embargo, la zona puede verse afectada por las pesquerías locales y otras actividades humanas, lo que afecta a las poblaciones de peces e invertebrados y formaciones coralinas. Nuestro estudio llena algunos vacíos de conocimiento de la biodiversidad marina en el Golfo de Papagayo que pueden contribuir a la conservación de la vida marina en el Pacífico Norte de Costa Rica.

Palabras clave: vacíos de conocimiento; Área de Conservación Guanacaste; áreas marinas desprotegidas; salud arrecifal; sobrepesca.

\section{REFERENCIAS}

Aburto-Oropeza, O., \& Balart, E.F. (2001). Community structure of reef fish in several habitats of rocky reef in gulf of California. Marine Ecology, 22(4), 283-305.

Alfaro, E.J., \& Cortés, J. (2012). Atmospheric forcing of cool subsurface water events in Bahía Culebra, gulf of papagayo, Costa Rica. Revista de Biología Tropical, 60(2), 173-186.

Alvarado, J.J., Beita-Jiménez, A., Mena, S., Fernández, C., Cortés, J., Sánchez-Noguera, C., ... GuzmánMora, A.G. (2018). Cuando la conservación no puede seguir el ritmo del desarrollo: Estado de salud de los ecosistemas coralinos del Pacífico Norte de Costa Rica. Revista de Biología Tropical, 66(Supl. 1), S280-S308.

Alvarado, J.J., Cortés, J., \& Reyes-Bonilla, H. (2012). Reconstruction of Diadema mexicanum bioerosion impact on three Costa Rican Pacific coral reefs. Revista de Biología Tropical, 60(Suppl. 2), 121-132.

Andrade-Vera, S., Bonifaz, M.J., Domínguez-Granda, L.E., \& Marín-Jarrín, J.R. (2017). Uso de la zona de rompiente de playas arenosas por larvas 
de corvina (Cynoscion spp.), Provincia del Guayas, Ecuador. Latin American Journal of Aquatic Research, 45(2), 431-442.

Arias, A., Cinner, J.E., Jones, R.E., \& Pressey, R.L. (2015). Levels and drivers of fishers' compliance with marine protected areas. Ecology and Society, 20(4), 19.

Beita-Jiménez, A., Alvarado, J.J., Mena, S., \& GuzmánMora, A.G. (2019). Benefits of protection on reef fish assemblages in a human impacted region in Costa Rica. Ocean and Coastal Management, 169, 165-170.

Brusca, R. (1974). A Handbook to the Common Intertidal Invertebrates of the Gulf of California Richard C. Brusca. The American Biology Teacher, 36(2), 126-127.

Camacho-García, Y.E., Gosliner T.M., \& Valdés, A. (2005). Field guide to the sea slugs of the tropical Eastern Pacific. California, USA: California Academy of Sciences.

Cortés, J. (2017). Marine biodiversity baseline for Área de conservación Guanacaste, Costa Rica: Published records. ZooKeys, 2017(652), 129-179.

Dittmar, T., \& Lara, R.J. (2001). Do mangroves rather than rivers provide nutrients to coastal environments south of the Amazon River? Evidence from long-term flux measurements. Marine Ecology Progress Series, 213, 67-77.

Dominici-Arosemena, A., Brugnoli-Olivera, E., CortésNúñez, J., Molina-Ureña, H., \& Quesada-Alpízar, M. (2005). Community structure of eastern Pacific reef fishes (Gulf of Papagayo, Costa Rica). Tecmiemh, 7(2), 19-41.

Dominici-Arosemena, A., \& Wolff, M. (2006). Reef fish community structure in the Tropical Eastern Pacific (Panamá): Living on a relatively stable rocky reef environment. Helgoland Marine Research, 60(4), 287-305.

Edwards, C.B., Friedlander, A.M., Green, A.G., Hardt, M.J., Sala, E., Sweatman, H.P., ... Smith, J. E. (2014). Global assessment of the status of coral reef herbivorous fishes: Evidence for fishing effects. Proceedings of the Royal Society Biological, 281(1774), 1-10.

Espinoza, M., \& Salas, E. (2005). Estructura de las comunidades de peces de arrecife en las Islas Catalinas y playa Ocotal, Pacífico Norte de Costa Rica. Revista de Biología Tropical, 53(3-4), 523-536.

Ferreira, C.E.L., Goncçalves, J.E.A., \& Coutinho, R. (2001). Community structure of fishes and habitat complexity on a tropical rocky shore. Environmental Biology of Fishes, 61(4), 353-369.

Fischer, W., Krupp, F., Schneider, W., Sommer, C., Carpenter, K.E., \& Niem, V.H. (1995). Guía FAO para la identificación de especies para los fines de la pesca.
Pacifico Centro-Oriental. Volumen I. Plantas e invertebrados. vol. I. Roma, Italia: FAO.

Fourriére, M., Alvarado, J.J., Cortés, J., Taylor, M.H., Ayala-Bocos, A., Azofeifa-Solano, J.C., ... Wolff, M. (2019). Energy flow structure and role of keystone groups in shallow water environments in Isla del Coco, Costa Rica, Eastern Tropical Pacific. Ecological Modelling, 396, 74-85.

Friedlander, A.M., Zgliczynski, B.J., Ballesteros, E., Aburto-Oropeza, O., Bolaños, A., \& Sala, E. (2012). The shallow-water fish assemblage of Isla del Coco National Park, Costa Rica : structure and patterns in an isolated, predator-dominated ecosystem. Revista de Biología Tropical, 60, 321-338.

Froese, R., \& Pauly, D. (2020). FishBase (version Feb 2018). In Y. Roskov, G. Ower, T. Orrell, D. Nicolson, N. Bailly, P.M. Kirk, ... L. Penev (Eds.), Species 2000 \& ITIS Catalogue of Life, 2020-04-16 Beta (digital version). Leiden, the Netherlands: Naturalis.

García-Hernández, V.C., Reyes-Bonilla, H., Balart, E.F., Ríos-Jara, E., Lluch-Cota, S.E., \& Serviere-Zaragoza, E. (2014). Comparación de la diversidad ecológica y composición de especies de ensambles de macroalgas, Macroinvertebrados bentónicos y peces en dos arrecifes rocosos tropicales. Revista de Biología Marina y Oceanografia, 49(3), 477-491.

Herrera, A., \& Bone, D. (2015). Dinámica temporal y espacial de la comunidad íctica y megabentónica en playas arenosas en relación a parámetros indicadores de aportes fluviales. Pan-American Journal of Aquatic Sciences, 9, 58-65.

Hickman, C.P. (1998). A field guide to sea stars and other echinoderms of Galápagos. Virginia, USA: Sugar Spring Press.

Hill, M.O. (1973). Diversity and Evenness: A Unifying Notation and Its Consequences. Ecology, 54(2), 427-432.

Jiménez-Valverde, A., \& Hortal, J. (2003). Las curvas de acumulación de especies y la necesidad de evaluar la calidad de los inventarios biológicos. Revista Ibérica de Aracnología, 8, 151-161.

Keen, A.M. (1972). Sea Shells of Tropical West America. A. Myra Keen. The Quarterly Review of Biology, 47(2), 240-240.

Marshall, D.J., Gaines, S., Warner, R., Barneche, D.R., \& Bode, M. (2019). Underestimating the benefits of marine protected areas for the replenishment of fished populations. Frontiers in Ecology and the Environment, 17(7), 407-413.

Mercier, A., Toral-Granda, V., Alvarado, J.J., \& Benavides Serrato, M. (2013). Isostichopus fuscus. 
The IUCN Red List of Threatened Species 2013, e.T180519A1642750

Morales-Ramírez, A. (2013). Un análisis sobre la situación de algunos de nuestros ecosistemas costeros: necesidad de una gestión integrada. Ambientico, 23(230), 16-26.

Moreno Pérez, I.J. (2019). Estructura de la comunidad de peces en la laguna costera de Navachiste, Sinaloa, México. La Paz, México: Centro de Investigaciones Biológicas de Noreste, S.C.

Naranjo-Madrigal, H. (2011). Biología pesquera de la langosta panulirus gracilis en playa Lagarto, guanacaste, Costa Rica. Revista de Biología Tropical, 59(2), 619-633.

R Core-Team. (2018). R: A language and environment for statistical computing. Version 3.5.2.R Foundation for Statistical Computing. Vienna, Austria. Retrieved from https://www.R-project.org/

Sibaja-Cordero, J., Camacho-García, Y.E., \& Vargas-Casti1lo, R. (2014). Riqueza de especies de invertebrados en playas de arena y costas rocosas del Pacífico Norte de Costa Rica. Revista de Biología Tropical, 62(4), 63-84.

Soler, G.A., Edgar, G.J., Thomson, R.J., Kininmonth, S., Campbell, S.J., Dawson, T.P., ... Stuart-Smith, R.D. (2015). Reef fishes at all trophic levels respond positively to effective marine protected areas. PLOS ONE, 10(10), e 0140270
StatSoft-Inc. (2011). STATISTICA (data analysis software system), version 10. Retrieved from https://www. statsoft.com/

Strain, E.M.A., Edgar, G.J., Ceccarelli, D., Stuart-Smith, R.D., Hosack, G.R., \& Thomson, R.J. (2019). A global assessment of the direct and indirect benefits of marine protected areas for coral reef conservation. Diversity and Distributions, 25(1), 9-20.

Ulate, K., Sánchez, C., Sánchez-Rodríguez, A., Alonso, D., Aburto-Oropeza, O., \& Huato-Soberanis, L. (2016). Latitudinal regionalization of epibenthic macroinvertebrate communities on rocky reefs in the Gulf of California. Marine Biology Research, 12(4), 389-401.

Villalobos-Rojas, F., Herrera-Correal, J., Garita-Alvarado, C.A., Clarke, T., \& Beita-Jiménez, A. (2014). Actividades pesqueras dependientes de la ictiofauna en el Pacífico Norte de Costa Rica. Revista de Biología Tropical, 62(4), 119-137.

Whittaker, R.H. (1960). Vegetation of the Siskiyou Mountains, Oregon and California. Ecological Monographs, 30(4), 407-407.

Windevoxhel-Lora, N., \& Cordoba-Muñoz, R. (1998). Inventario de los Humedales de Costa Rica. Costa Rica: IUCN Convenio Bilateral Costa Rica Holanda.

Yaney-Keller, A., Santidrián-Tomillo, P., Marshall, J.M., \& Paladino, F.V. (2019). Using unmanned aerial systems (Uas) to assay mangrove estuaries on the pacific coast of Costa Rica. PLoS ONE, 14(6), e 0217310.

\section{See Digital Appendix at: / Ver Apéndice digital en: revistas.ucr.ac.cr}

